\title{
A variety of textures in mantle xenoliths of peridotites and pyroxenites from Yakutian pipes: petrological interpretation
}

\author{
Taisia A. Alifirova, Lyudmila N. Pokhilenko \\ V.S. Sobolev Institute of Geology and Mineralogy SB RAS, Novosibirsk, Russia
}

\section{Introduction}

Mantle rock texture often experiences significant transformations by the action of superimposed processes. Among these are deformation and recrystallization of mineral aggregates, reaction interaction of mineral phases in different equilibrium conditions of association, exsolution textures of minerals, metasomatic effect on rocks. It is not practical to determine primary texture of rocks, but it can be reconstructed from the preserved relict areas. This work is an attempt to evaluate the contribution of superimposed processes to change and transformation of mantle rocks.

Methods of optical and electron scanning microscopy and microprobe analysis were applied.

\section{Xenolith Petrography}

16 peridotite and pyroxenite xenoliths from Udachnaya, Mir, Obnazhennaya kimberlite pipes were studied. This set of xenoliths represents a wide range of depths in lithosphere mantle section of the Siberian craton and comprises material of three lithosphere blocks, which are constituents of the craton basement.

Rock-forming minerals are represented by olivine (Fo 90.4-92.8 mol.\%), orthopyroxene (En 87.5-92.7 mol.\%), clinopyroxene (mainly Di with touch of En, Ts, U, Jd), garnet (Pyrope 57.6-76.1 mol\%, Almandine 11.3-28.3 mol\%, Uvarovite $0.5-13.3 \mathrm{~mol} \%$, Knorringite 0-14.6 mol.\%) and sometimes phlogopite. The following accessory and secondary minerals are determined: spinelides (several generations), perovskite, ilmenite, apatite, phlogopite, chlorite, carbonate, Cl-containig phases, Ca-Ti-phases, secondary clinopyroxene and olivine, high temperature sulfides (pyrrhotite, pentlandite, chalcopyrite, dzherfisherite) and serpentine.

In one of the commonly accepted classifications (Mercier, Nicolas, 1975) rocks of lherzolite paragenesis are subdivided into the following structural types: protogranular, porphyroclastic, equigranular and transitional between equigranular and protogranular.

A number of deformation textures in rocks and minerals were revealed: pyroxene curvature cracks cleavage (Fig. 1, a,b), polysynthetic twins and related small cracks in pyroxenes (Fig. 1, f), kink-band textures and olivine grains cleavage (Fig. 1, c), textures of strong deformation and partial re-crystallization of olivine and (rarely) orthopyroxene grains with formation of porphyroclasts and neoblasts. Deformations are typical of the samples with porphyroclastic texture, nevertheless they are found in all xenoliths.

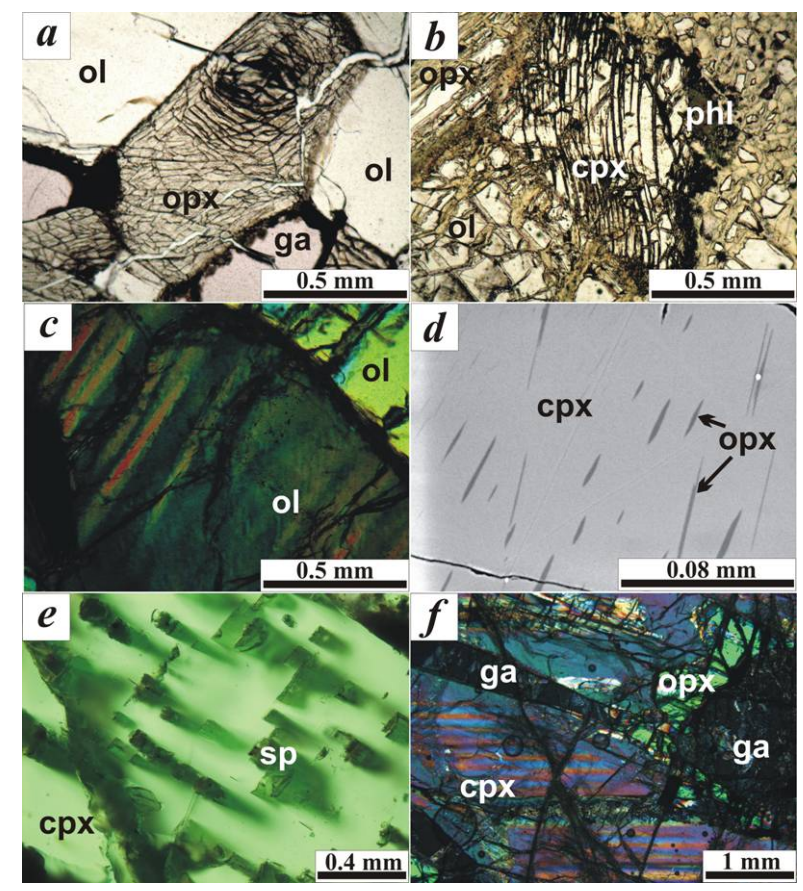

Fig. 1. a - twist of cleavage cracks in orthopyroxene (opx) grain; b - clinopyroxene (cpx) grain curvilinear cracks of cleavage; c - kinking texture in olivine (ol) grain; d - thin lamellae of orthopyroxene in clinopyroxene grain; e - lamellae of spinel (sp) exsolved in clinopyroxene grain; f - polysynthetic twins in clinopyroxene, garnet (ga) lamella transition into grain in host mineral and line of orthpyroxene grains in contact with host mineral; phl - phlogopite.

Exsolution textures of minerals were found in all studied xenoliths. We noted all stages of the process: lamellae creation (Fig. 1, d, e) - enlargement of lamellae (Fig. 1, f) - transformation of lamella part into grain - complete lamella transformation into grain in 
host mineral (Fig. 1, f) - replacement of grain from host mineral (Fig. 1, f).

Garnet, clinopyroxene, spinelides are found in orthopyroxene among the exsolved minerals and orthopyroxene, garnet, spinelides - in clinopyroxene.

Reaction formations in xenoliths are represented by rims around garnet and orthopyroxene. Garnet reaction rims often have complicated zonal structure. Phlogopite and spinelides are in the outer parts of the rims (Fig. 2, a, d), microgranular pyroxene and spinel make up the inner parts (Fig. 2, a, b). Orthopyroxene reaction rims contain spinel, carbonates, chlorite, serpentine and probably amphibole.

\section{Accessory mineralization}

Phlogopite makes up tabular crystals (Fig. 2, e), flaky aggregates. Flake grains from fraction of $\mathrm{mm}$ up to 1 $\mathrm{cm}$ in length occur as isolations, in garnet reaction rims and in the inclusions of pyroxenes.

Sometimes phlogopite flakes are curved and contain spinelide, sulfide, apatite, carbonate and ilmenite inclusions. Close intergrowth with sulfides (Fig. 2, c) and clinopyroxene are observed.

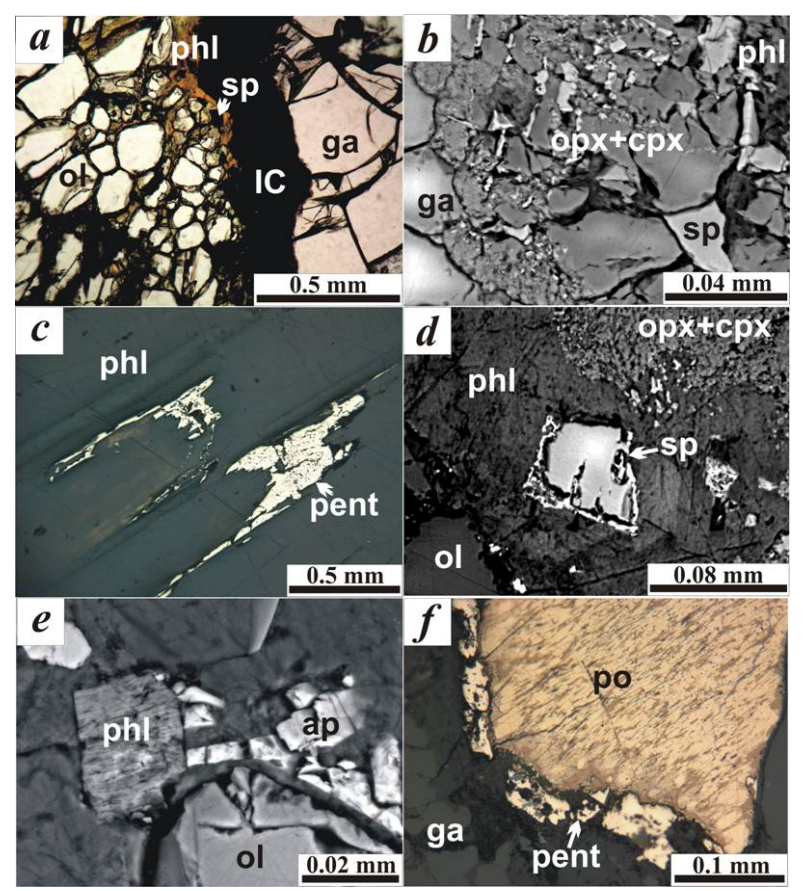

Fig. 2. a - garnet (ga) grain rounded by inner corona (IC) and outer one with spinel (sp) grains and flaky aggregate of phlogopite (phl); b - microgranular aggregate of pyroxenes $(\mathrm{opx}+\mathrm{cpx})$ and spinel (sp) formed inner parts of rim around garnet grain; $\mathrm{c}-$ close intergrowth between phlogopite (phl) and pentlandite (pent); d - zonal grain of spinel (sp) in outer part of garnet rim with later spinelide generation grown; e interstitial phlogopite and apatite (ap) crystals; f sulfide isolations with exsolution textures between garnet grains with later pentlandite generation grown; po-pyrrhotite, ol - olivine.
Minor amounts of spinelides are found in the xenoliths. They make up vermiform, round, resorbed, zonal grains (Fig. 2, d) and skeleton crystals. Several spinelide generations are noted (Fig. 2, d). Sometimes spinelide is observed in the nucleus of garnet granular aggregates. Spinelides often occur in association with sulfides forming close intergrowths.

Apatite makes up colorless small well cut grains and skeleton crystals (Fig. 2, e).

Sulfides are found in the samples as globular inclusions in minerals, isolations between the grains of other minerals (Fig. 2, f), which fill cracks in xenoliths, thin needle-shaped aggregates, which form isolations together with carbonates. Exsolution textures can be observed within sulfide isolations (Fig. 2, f). Several generations of sulfide mineralization are noted (Fig. 2, f).

\section{Discussion}

This mineralogical-petrographic study of peridotite and pyroxenite xenoliths has revealed that tectonic deformations significantly effect the formation of rock texture. The described deformation structures are the result of mechanic influence on rocks and subsequent transformations. The process of material recrystallization is of great importance in textural transformation of rocks. Softening of rocks texture, caused by the stress during deformation, leaves deformation traces on olivine and orthopyroxene porphyroclasts. Neoblasts of these minerals are result of recrystallization. Granular aggregate with mosaic texture is formed by action of deformations. As the degree of recrystallization increases, relict porphyroclasts decrease in abundance and grains of uniformly granular aggregate enlarge. The following transformation cycles of rocks textures become evident: 1) protogranular - porphyroclastic equigranular, 2) protogranular - equigranular porphyroclastic.

The study of exsolution textures of pyroxenes reveals transition between different morphological phases exsolved in minerals-concentrators. Lamellae creation and enlarge with subsequent recrystallization as a result of temperature decrease or pressure increase. Mineral (solid phase solution) becomes unstable in the changed P-T conditions and gets rid of the "excess" phases. These phases concentrate along the weakest crystallographic directions of the host mineral lattice, within the defects of crystalline lattice and at last along the host mineral grain bordering with other minerals. Removal of precipitated mineral phases from the grains periphery is an easier process, amount of thin lamellae decreases on the periphery. More coarse lamellae formed with time from thin lamellae in the central part of grains. Sometimes grains-"inclusions", which are also a result of lamellae recrystallization, occur. Thin garnet lamellae often recrystallize to form more stable aggregate of thin garnet flakes obliquely oriented to general direction of lamellae in the clinopyroxene 
texture. These flakes subsequently recrystalize to form more stable polygonal grains.

The following reactions of dissolution of solid solutions are used to describe the process of dissolution of our pyroxenes:

1. $\left.\mathrm{Ca}_{1-\mathrm{x}} \mathrm{Mg}_{1+\mathrm{x}} \mathrm{Si}_{2} \mathrm{O}_{6} \rightarrow(1-\mathrm{x})\left(\mathrm{CaMgSi}_{2} \mathrm{O}_{6}\right)+\mathrm{x} \mathrm{Mg}_{2} \mathrm{Si}_{2} \mathrm{O}_{6}\right)$

2. $\left(\mathrm{CaAl}_{2} \mathrm{SiO}_{6}+\mathrm{CaR}^{2+} \mathrm{Si}_{2} \mathrm{O}_{6} \rightarrow \mathrm{Ca}_{2} \mathrm{R}^{2+} \mathrm{Al}_{2} \mathrm{Si}_{3} \mathrm{O}_{12}\right.$;

3. $\mathrm{MgAl}_{2} \mathrm{SiO}_{6}+\mathrm{MgR}^{2+} \mathrm{Si}_{2} \mathrm{O}_{6} \rightarrow \mathrm{Mg}_{2} \mathrm{R}^{2+} \mathrm{Al}_{2} \mathrm{Si}_{3} \mathrm{O}_{12}$;

4. $\left(\mathrm{CaMgSi}_{2} \mathrm{O}_{6}+\mathrm{MgAl}_{2} \mathrm{O}_{4}\right) \mathrm{ss} \rightarrow \mathrm{CaMgSi}_{2} \mathrm{O}_{6}+\mathrm{MgAl}_{2} \mathrm{O}_{4}$;

5. $\left\{2 \mathrm{Mg}_{2} \mathrm{SiO}_{4}+2 \mathrm{MgCrAlSiO}_{6}\right\} \mathrm{ss} \rightarrow 2 \mathrm{Mg}_{2} \mathrm{Si}_{2} \mathrm{O}_{6}+$ $\left\{\mathrm{MgCr}_{2} \mathrm{O}_{4}+\mathrm{MgAl}_{2} \mathrm{O}_{4}\right\}$ ss;

6. $\left\{\mathrm{x} \mathrm{Mg}_{2} \mathrm{SiO}_{4}+\mathrm{y} \mathrm{CaMgSi} \mathrm{O}_{6}+\mathrm{z} \mathrm{CaAl}_{2} \mathrm{SiO}_{6}\right\} \mathrm{ss} \rightarrow\{(\mathrm{x}+\mathrm{y})$ $\left.\mathrm{CaMgSi}_{2} \mathrm{O}_{6}+(\mathrm{z}-\mathrm{x}) \mathrm{CaAl}_{2} \mathrm{SiO}_{6}\right\} \mathrm{ss}+\mathrm{xMgAl}_{2} \mathrm{O}_{4}$;

7. $\left\{\mathrm{x} \mathrm{Mg}_{2} \mathrm{SiO}_{4}+\mathrm{y} \mathrm{Mg}_{2} \mathrm{Si}_{2} \mathrm{O}_{6}+\mathrm{z} \mathrm{MgAl}_{2} \mathrm{SiO}_{6}\right\} \mathrm{ss} \rightarrow\{(\mathrm{x}+\mathrm{y})$ $\left.\mathrm{Mg}_{2} \mathrm{Si}_{2} \mathrm{O}_{6}+(\mathrm{z}-\mathrm{x}) \mathrm{MgAl}_{2} \mathrm{SiO}_{6}\right\} \mathrm{ss}+\mathrm{x} \mathrm{MgAl}_{2} \mathrm{O}_{4}$.

Reactions 1 - by Pokhilenko N.P. (1990); 2,3 - by Pokhilenko L.N. et al. (2007); 4,5,6,7 -by Garrison, Taylor (1981).

Reaction rims around garnet are of special interest in respect to the relations of minerals in the xenoliths.

Similar to Godard, Martin (2000) two zones were distinguished in the garnet rims of our samples. According to the reaction garnet + olivine $\rightarrow$ spinel + orthopyroxene + clinopyroxene, aggregate of orthopyroxene, clinopyroxene and spinelides are distinguished in the internal zone. Phlogopite + spinelide are situated in the external zone. On addition of metasomatic component chlorite, amphibole, phlogopite, ilmenite, calcite and perovskite form in the rim.

Phlogopite occurs as individual large tabular crystals and grains. It is in equilibrium with other minerals and differs in composition from secondary phlogopite filling the veins. Winternburn et al. (1990) was first to give similar description of phlogopite of primarily metasomatic origin. Other phases of accessory mineralization are of later origin relative to the minerals of basic paragenesis. Probably secondary metasomatic agent was enriched in $\mathrm{Fe}, \mathrm{Ti}, \mathrm{Al}, \mathrm{P}, \mathrm{Ca}, \mathrm{S}$, $\mathrm{K} \pm \mathrm{CO}_{2}, \mathrm{H}_{2} \mathrm{O}$. Skeleton crystals of spinelides and apatite, zonal spinelide grains are most likely connected with fast growth of these minerals and supersaturation in the mineral forming medium.

Sulfides from the samples are different in morphology, mineral composition and origin. Primary globular inclusions of sulfides are the result of silicate and sulfide liquid liquation. Sulfides in interstices, veins and accretions refer to the later generations. Exsolution textures of sulfide isolations are still little studied. Processes similar to ones in pyroxenes occur in some of sulfide grains: recrystallization and enlargement of exsolved phases. The largest amount of sulfides is found in the samples with protogranular texture and minimal - with equigranular texture.

\section{Conclusions}

Thus from the results obtained it may be deduced that:

1) transformation sequence of rocks texture with formation of different textural types under the effect of the main factors - deformation and recrystallization was determined;

2) various exsolution textures with retention of transformation stages from creation of thin lamellae in the host mineral to the formation of individual grains beyond the host mineral were revealed;

3) secondary metasomatic products formed at high growth rates and supersaturation.

\section{Referencies}

Garrison J.R.Jr., Taylor L.A., 1981. Petrogenesis of pyroxene-oxide intergrowths from kimberlite and cumulate rocks: co-precipitation or exsolution? American Mineralogist, 66, 723-740.

Godard G., Martin S., 2000. Petrogenesis of kelyphites in garnet peridotites: a case study from the Ulten zone, Italian Alps. Journal of Geodynamics, 30, 117-145.

Mercier J.-C.C., Nicolas A., 1975. Textures and fabrics of upper-mantle peridotites as illustrated by xenoliths from basalts. Journal of Petrology, 16, № 2, 454-487.

Pokhilenko L.N., Pokhilenko N.P., Stenina N.G., Sobolev N.V., 2007. The exolution lamellae in clinopyroxene from xenolith of complex eclogite of the kimberlite pipe Obnazhennaya (Yakutia). Proceedings of the $2^{\text {nd }}$ Kimberlite Conference "Crystallogenesis and Mineralogy", St. Peterburg, p. 325-327.

Pokhilenko N.P., 1990. Mantle paragenesis in kimberlites their origin and prospecting significance. Doctoral thesis. Novosibirsk. SB AS USSR, IGG.

Winterburn P.A., Harte B., Gurney J.J., 1990. Peridotite xenoliths from the Jagersfontein kimberlite pipe: I. Primary and primary-metasomatic mineralogy. Geochimica et Cosmochimica Acta, 54, 329-341. 